\title{
Estimation of peptide concentration by a modified BCA assay
}

Krishan N. Kapoor ${ }^{1}$, Danielle T. Barry ${ }^{1}$, Robert C. Rees ${ }^{1}$, I. Anthony Dodi ${ }^{1}$, Stephanie E.B. McArdle ${ }^{1}$, Colin S. Creaser ${ }^{2}$ and Philip L.R. Bonner ${ }^{1 *}$.

1 School of Science and Technology, Nottingham Trent University, Nottingham, NG11 8NS, UK

2 Centre for Analytical Science, Department of Chemistry, Loughborough University, Leicestershire, LE11 3TU, UK

Corresponding author:

*Philip Bonner.

$\begin{array}{ll}\text { Telephone: } & +44(0) 1158488068 \\ \text { Fax: } & +44(0) 1158483384 \\ \text { Email: } & \text { philip.bonner@ntu.ac.uk }\end{array}$

Abstract

Although biuret based protein assays are theoretically applicable to peptide measurement, there is a high level of inter-peptide variation, determined largely by peptide hydrophobicity. This variation in peptide reactivity can be significantly reduced by heat-denaturation of peptides at $95{ }^{\circ} \mathrm{C}$ for 5 minutes in the presence of $0.1 \mathrm{M} \mathrm{NaOH}$ containing $1 \%(\mathrm{w} / \mathrm{v}) \mathrm{SDS}$, prior to incubation for $30 \mathrm{~min}$ at $37^{\circ} \mathrm{C}$ in BCA standard working reagent. This modification to the standard bicinchoninic acid (BCA) assay protocol allows for an accurate, rapid and economical estimation of the peptide concentration within an unknown sample.

Key words: Assay; BCA; bicinchoninic acid; estimation; measurement; peptide.

There are a wide range of methods for estimating protein concentration, driven by the rise in proteomics/peptidomics over the last few years, but fewer approaches are available for quantifying the peptide content of a sample. Measurement of UV absorbance is often recommended however absorbance at $280 \mathrm{~nm}$ is influenced by frequency of tyrosine and tryptophan (as well as nucleotide and nucleic acid contamination), whilst absorbance at $210 \mathrm{~nm}$ is complicated by other organic compounds [1]. A number of fluorescent and luminescent approaches to peptide quantification are in use $[2,3,4]$, however, the majority of these methods either react with the peptide amino-terminus or are biased towards certain amino acids within the sequence, and are frequently sensitive to photo-bleaching. Colorimetric protein assays, including the biuretbased Lowry [5] and bicinchoninic acid (BCA) [6] assays are occasionally utilised 
to quantify peptide $[7,8]$, though neither is recommended for this application. Currently, there are no convenient published colorimetric methods for peptide quantification. In the present study we demonstrate a modification which improves the applicability of the BCA assay to quantification of the peptide concentration in a sample.

A bicinichoninic acid (BCA) protein assay kit and glycerol were supplied by Fisher Scientific (UK). Falcon ${ }^{\mathrm{TM}}$ 96-well plates were supplied by BD Biosciences (USA). SDS was supplied by Melford (UK). The phosphopeptides and non-phosphorylated counterparts (hydrophilic scores given in brackets) ALR(pS)NFERI (0.3), SQKGQESE(pY) (1.1/0.9), TVEAVA(pY)APK (0.1/-0.1), and YI(pS)PLKSPY (-0.5) were synthesised by Pepceuticals (UK). Peptides VIVHSATGFKQSSKALQRPVASDFEPQ (0.0), LYGFNLVIVHSATGFKQSSK (HS: -0.5), VHSATGFKQSSKALQRPVASD (0.2) and QAGILARNLUPMVATVQGQN (-0.4) were supplied by Alta Biosciences (UK). Peptide LSRH (0.3) was synthesised at Nottingham Trent University. Predicted hydrophilic scores were determined using the Peptide Property Calculator at Innovagen (http://www.innovagen.se/). Rabbit muscle aldolase and bovine liver catalase was supplied by GE Healthcare (UK). All other reagents were procured from Sigma-Aldrich (UK). Peptide stock solutions were dissolved in DMSO to $10 \mathrm{mg} / \mathrm{ml}$. Cell lines (JY and T2) were cultured in RPMI $1640+10 \%(\mathrm{v} / \mathrm{v}) \mathrm{FCS}, 20 \mathrm{mM}$ L-glutamine at $37{ }^{\circ} \mathrm{C}$ in a $5 \% \mathrm{CO}_{2}$ atmosphere, and subcultured according to standard protocols when in log-phase growth and $80 \%$ confluency.

Standard method: Fifty microlitres of sample was mixed with $50 \mu \mathrm{l}$ of $0.2 \mathrm{M} \mathrm{NaOH}$ containing $2 \%(\mathrm{w} / \mathrm{v}) \mathrm{SDS}$ in $0.5 \mathrm{ml}$ microfuge tubes, and heated to $95{ }^{\circ} \mathrm{C}$ for 5 minutes using a Biometra Uno Thermoblock (Germany). After cooling to room temperature $25 \mu \mathrm{l}$ of this sample mixture was transferred to a microplate (in triplicate) followed by $200 \mu \mathrm{l}$ of BCA standard working reagent (SWR) (prepared by mixing $B C A$ reagent $A$ with reagent $B$ in a 50:1 ratio) [6]. The microplate was covered (sealing film: SLS, UK), incubated at $37{ }^{\circ} \mathrm{C}$ for 30 minutes and the absorbance read at $570 \mathrm{~nm}$ (microplate reader: model 680 Bio-Rad, UK).

A 700-watt microwave oven may be used as an alternative to the $37^{\circ} \mathrm{C}$ incubation step in the BCA assay. Prior to heating in the microwave, the microplate wells which did not contain any sample were filled with $200 \mu$ of water (to prevent sample boiling and reduce inter-plate variation). The microplate was covered with sealing film and placed on the edge of the microwave's revolving 
tray for two concurrent 15 -second intervals. To reduce the intra-plate heating variation the microplate was manually rotated by 180 degrees after the first incubation period. Following microwave-incubation, the microplates were cooled to room temperature and the absorbance read as above.

Standard proteins (aldolase, BSA, casein and catalase: $5 \mathrm{mg} / \mathrm{ml}$ ) in $20 \mathrm{mM}$ Tris/ $\mathrm{HCl} \mathrm{pH} 8.0$ were digested by incubation with $1 \%(\mathrm{w} / \mathrm{w})$ trypsin for 72 hours at $37^{\circ} \mathrm{C}$ in a orbital incubator (SI50, Stuart, UK). The undigested protein was removed by the addition of TCA to a final concentration of $7.2 \%(w / v)$ [9], followed by centrifugation at $10,000 \mathrm{~g}$ for 20 minutes. After the supernatant was diluted by $1: 10$ in $0.1 \mathrm{M} \mathrm{NaOH}$ containing $1 \%(\mathrm{w} / \mathrm{v})$ SDS, the peptide content of the supernatant was measured (as above).

Guinea pig liver $(10.0 \mathrm{~g}$ ) was homogenised in $100 \mathrm{ml}$ of $50 \mathrm{mM}$ Tris/ $\mathrm{HCl}$ using a Waring Blender and clarified by centrifugation at 20,000 g for 30 minutes (Allegra $X-15 R$, Beckman UK). Supernatant proteins were precipitated by ammonium sulphate $\left(80 \%\right.$ saturation) with stirring at $4{ }^{\circ} \mathrm{C}$ for 4 hours. The precipitate was collected by centrifugation $\left(10,000 \mathrm{~g}\right.$ for 45 minutes at $4{ }^{\circ} \mathrm{C}$ ), then dissolved and dialysed overnight against a $10 \mathrm{mM}$ trimethylamine- $\mathrm{HCl} \mathrm{pH} 8.0$ buffer. The protein concentration was determined [6] and $0.5 \mathrm{~g}$ was tryptically digested as above. Undigested material was precipitated by the addition of 9 volumes of icecold acetone and incubated overnight at $-20^{\circ} \mathrm{C}$, then centrifuged at $10,000 \mathrm{~g}$ for 20 minutes at $4{ }^{\circ} \mathrm{C}$. The peptide supernatant was dried using inert gas $\left(\mathrm{N}_{2}\right)$ in a glass container. Peptide fragments were prepared from BSA and two lymphoblastic cell lines ( $\mathrm{JY}$ and T2) using a similar method. After drying, peptides from digests were weighed, redissolved in DMSO and assayed by the modified peptide BCA (as above).

Figure 1 illustrates that linear and reproducible standard curves may be produced from tryptic digests of protein extracted from guinea pig liver, two lymphoblastic cell lines (JY and T2) and of BSA. We have found that using a standard BCA protocol [6] to quantify peptides in solution $[7,8]$ produced a wide variation in inter-peptide reactivity (see Table 1 ). This was largely dependent upon two variables; peptide length and hydrophilic score, which together amount to a Spearman's rank correlation of $0.785(P<0.01)$ with BCA reactivity. In order to minimise this variation, a range of solubilisation reagents were tested including the addition of up to $5 \%(\mathrm{w} / \mathrm{v})$ SDS, $10 \%(\mathrm{v} / \mathrm{v})$ methanol, $0.15 \%(\mathrm{w} / \mathrm{v})$ deoxycholate, $100 \mathrm{mM} \mathrm{Na} \mathrm{HPO}_{4}, 0.1 \mathrm{M} \mathrm{NaOH}$, and various combinations thereof 
(data not shown). Table 1 demonstrates that solubilising the peptides at 0.5 $\mathrm{mg} / \mathrm{ml}$ in $0.1 \mathrm{M} \mathrm{NaOH}$ containing $1 \%(\mathrm{w} / \mathrm{v})$ SDS (coupled with heating at $95{ }^{\circ} \mathrm{C}$ for 5 minutes) reduced intra-peptide variability by $32 \%$ for the synthetic peptides tested and by $52 \%$ if the assay was restricted to nonamers and decamers (statistically significant to $\mathrm{P}<0.01$ using student $\mathrm{T}$-test carried out on pooled SD values of assays performed using SDS/ $\mathrm{NaOH}$ and water). Similar patterns were observed for tryptic digests of standard proteins and of cell lysates.

A range of incubation times was examined (data not shown), the recommended optimum incubation of 30 minutes using SWR of a 50:1 reagent $A: B$ ratio was sufficient for the concentration range examined. Nevertheless, for measurement of low abundance peptides, alteration of the BCA SWR [6] to include a higher concentration of $\mathrm{CuSO}_{4}$, or longer incubation periods may prove fruitful. Figure 1 illustrates standard calibration curves produced from tryptic digests of biological material are linear between 0.01 and $1.0 \mathrm{mg} / \mathrm{ml}$, similar results were observed with both the synthetic peptides and protein digests tested. The alteration to the BCA method had no impact on the stability of the reaction, as with the standard assay there is little upwards drift in colour intensity once the plate is removed from incubation at $37^{\circ} \mathrm{C}$.

The use of microwave-incubation [10] allows for a rapid assay method, however inter-well variability was slightly higher than the standard $37^{\circ} \mathrm{C}$ incubation (data not shown). Additionally, the microwave-incubation was not sufficient to replace the peptide denaturing step, as microwave-incubation of non-denatured samples in the presence of $0.1 \mathrm{M} \mathrm{NaOH}$ containing $1 \%(\mathrm{w} / \mathrm{v})$ SDS only reduced interpeptide $B C A$ variation by $5 \%$ (similar to an unheated control: data not shown).

These modifications to the BCA assay allow for the rapid and accurate quantification of a sample's peptide concentration with standard laboratory reagents and equipment. The methods outlined above demonstrate that peptides may be assayed following precipitation of contaminating proteins by solvents or TCA. However, whilst the BCA assay carries a high degree of flexibility, it does have minor drawbacks which can be avoided by appropriate cleanup procedures. As the full compatibilities of the modified assay are yet to be determined it is recommended that an appropriate standard peptide or protein digest curve is prepared in the same matrix as samples. 


\section{References}

[1] C.M. Stoscheck. Quantitation of Protein. Meth. Enz. 182 (1990), pp. 50-69.

[2] E. Schiltz, D.K. Schnackerz, and R.W. Gracy. Comparison of ninhydrin, fluorescamine, and o-phthaldialdehyde for the detection of amino acids and peptides and their effects on the recovery and composition of peptides from thinlayer fingerprints. Anal Biochem. 79 (1977), pp. 33-41.

[3] W.W. You, R.P. Haughland, D.K. Ryan, Haughland, R.P. 3-(4Carboxybenzoyl)quinoline-2-carboxaldehyde, a reagent with broad dynamic range for the assay of proteins and lipoproteins in solution. Anal Biochem. 244. (1997), pp. 277-282.

[4] D.R. Coghlan, J.A. Mackintosh \& P. Karuso. Mechanism of Reversible Fluorescent Staining of Protein with Epicocconone. Org. Lett. 7. (2005), pp. 24012404.

[5] D. Lowry, N.J. Rosebrough, A.R. Farr \& R.J. Randall. Protein measurement with Folin phenol reagent. J Biol Chem 193. (1951), pp. 265-275.

[6] P.K. Smith, R.I. Krohn, G.T. Hermanson, A.K. Mallia, F.H. Gartner, M.D. Provenzano, E.K. Fujimoto, N.M Goeke, R.J. Olson \& D.C. Klenk. Measurement of protein using bicinchoninic acid. Anal. Biochem. 150. (1985), pp. 76-85.

[7] Y. Hua \& R.H. Scheller. Three SNARE complexes cooperate to mediate membrane fusion. Proc Natl Acad Sci U S A. 98. (2001), pp. 8065-8070.

[8] C. Faber, H. P. Stallmann, D. M. Lyaruu, J. M. A. de Blieck, Th. J. M. Bervoets, A. van Nieuw Amerongen and P. I. J. M. Wuisman. Release of antimicrobial peptide Dhvar-5 from polymethylmethacrylate beads. J Antimicrob Chemother. 51. (2003), pp. 1359-1364.

[9] R.E. Brown, K.L. Jarvis, and K.J. Hyland. Protein measurement using bicinchoninic acid: Elimination of interfering substances. Anal Biochem. 180. (1989), pp. 136-139.

[10] R.E. Akins \& R.S. Tuan. Measurement of protein in 20 seconds using a microwave BCA assay. Biotechniques. 12. (1992), pp. 496-9.

\section{Acknowledgements}

The authors would like to dedicate this publication to the memory of our valued colleagues and friends, Danielle Barry and Tony Dodi, both of whom are greatly missed. Our thanks also go to Dr. S. Patwardhan (NTU) for synthesis of the LSRH peptide and Dr. C. Riley (NTU) for donation of the VIVHSATGFKQSSKALQRPVASDFEPQ, LYGFNLVIVHSATGFKQSSK and QAGILARNLVPMVATVQGQN peptides. Professor Robert Rees and Dr. Stephanie McArdle are supported by The John and Lucille van Geest Foundation. We also 
acknowledge support from the E.U. funded ENACT project (LSHC - CT-2004503306).

Figure 1: Peptide BCA standard graphs were produced from peptides derived from the tryptic digests of BSA, guinea pig liver protein and two cell lines (JY and T2) as per materials and methods. Peptides in DMSO were diluted in $0.1 \mathrm{M} \mathrm{NaOH}$ containing $1 \%(\mathrm{w} / \mathrm{v})$ SDS prior to heating at $95^{\circ} \mathrm{C}$ for 5 min and a BCA assay carried out in a microplate. The samples were then read at $570 \mathrm{~nm}$.

Table 1: Mean absorbance (at $570 \mathrm{~nm}$ ) and standard deviation ( \pm ) of synthetic and tryptically derived peptide populations assayed by BCA assay with or without denaturing in $1 \%(\mathrm{w} / \mathrm{v})$ SDS in $0.1 \mathrm{M} \mathrm{NaOH}$. See materials for synthetic peptide sequences. Standard protein digests: peptides from aldolase, BSA, casein and catalase. Biological material digests: peptides from $\mathrm{JY}$ and $\mathrm{T} 2$ cell lines and $\mathrm{a}$ guinea pig liver homogenate.

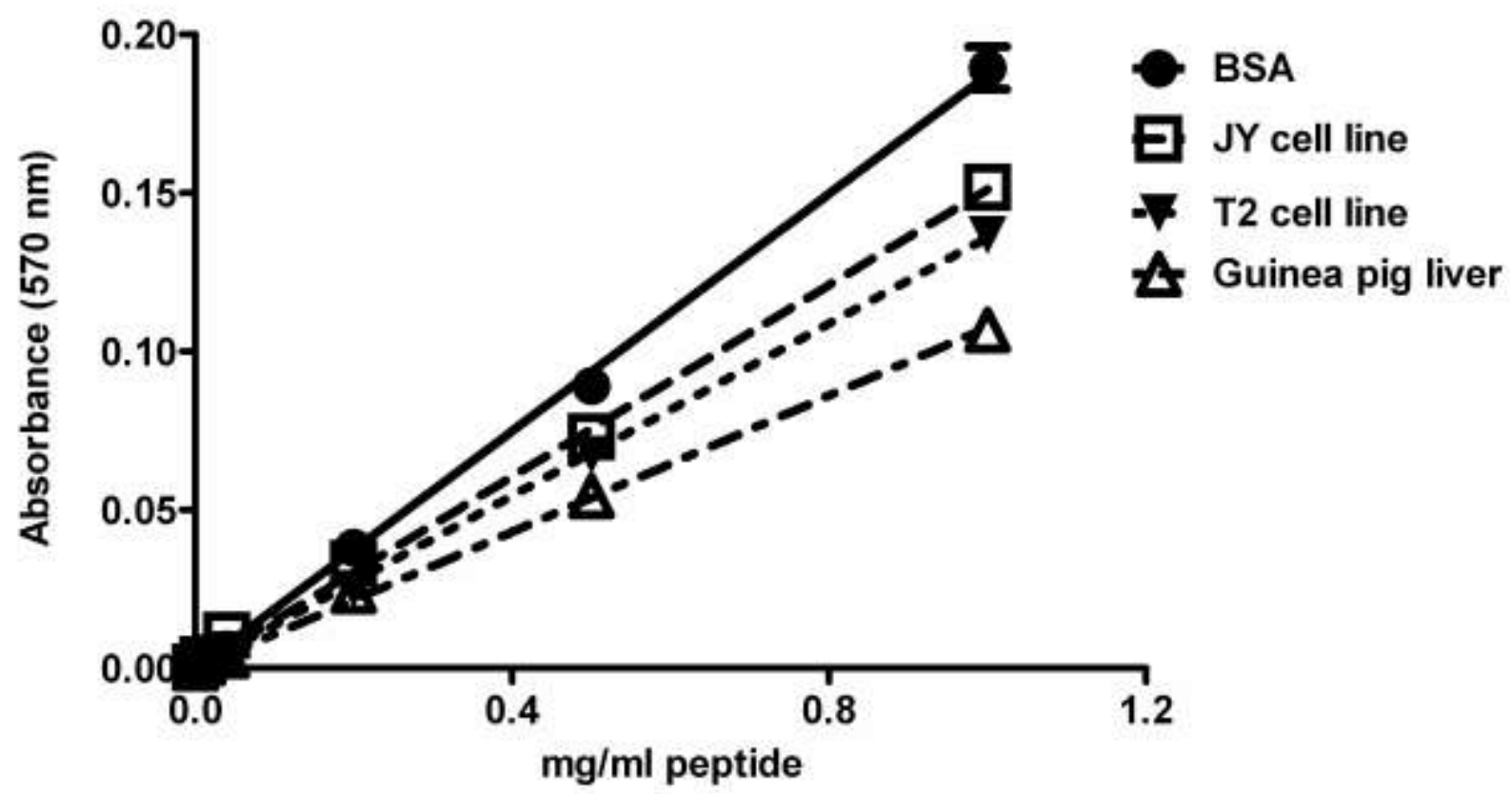

Figure 1 
Figure 2

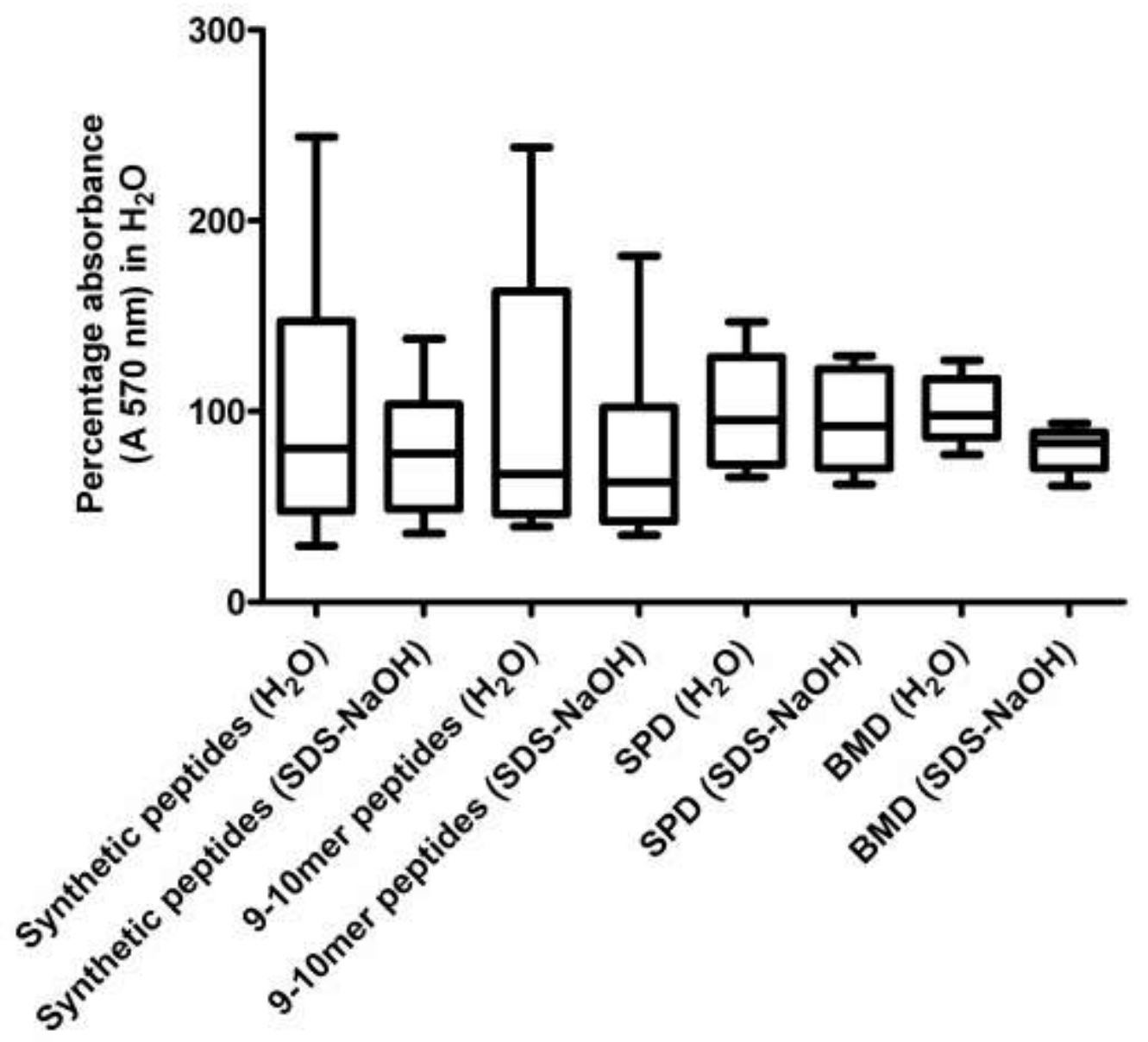

Peptide population assayed 